\title{
The Influence of Working Capital Management on the Food Industry Enterprises Profitability
}

\author{
Anna Bieniasz' ${ }^{1}$ Zbigniew Gołaś
}

ABSTRACT

\begin{abstract}
The article presents the results of working capital management efficiency in the food industry in Poland and selected countries of the Eurozone. The research was conducted on the basis of the unpublished data by the Polish Central Statistical Office in the trade structure and dimension of food industry enterprises in Poland in the period of 2005-2009, and comparatively, in respect of the food sector in selected Eurozone countries. The working capital management efficiency was assessed by means of the inventory, accounts receivables, current liabilities turnover cycles, cash conversion cycle, and in respect of the obtained rates of return from non-financial assets. The research proved that in the food industry sectors with the shortest working capital cycles, relatively higher rates of profitability were obtained. A favorable influence of working capital cycles reduction of the profitability was also verified by means of a multiple regression analysis.
\end{abstract}

KEY WORDS: $\quad$ working capital, rate of return, food industry

JEL Classification: F30, G30, G31

'Poznań University of Life Sciences - Department of Economics and Social Sciences, Poland

\section{Introduction}

In the financial theory and economic practice, a high level of current assets, through the generation of excessive liquidity costs, exercises a negative influence on the company profitability, whereas their insufficient level may increase a risk of the loss of liquidity, and as a consequence, lead to a range of difficulties in maintaining undisturbed operation of an enterprise (Van Horne and Wachowicz, 2004). The level of current assets should thus be optimized in every company. Nonetheless, this optimization should concern not only the assets level itself, but also their sources of financing. This entails a need of working capital management, which

Corespondence concerning to this article should be addressed to: bieniasz@up.poznan.pl is taking decisions that maintain a balance between two contrary objectives of the ability of value creation and liquidity (Shin and Soenen, 1998). At present, due to an increasing pressure to create shareholders values, monitoring of an optimum level of working capital determinants (e.g. inventory, accounts receivables, cash and current liabilities) becomes more important (Afza and Nazir, 2009). In numerous enterprises, current assets constitute a half or more of the total asset value, and at the same time, they are financed from various sources. To some extent, it naturally entails a need of shaping their level in a rational manner.

Cash conversion cycle is a basic tool applied in the assessment of working capital management efficiency (Richards and Laughlin, 1980). It is based on an analysis of three partial cycles, that is, the inventory and accounts receivables, which mark the length of a so- 

tion of Activities] 2007 in conformity to NACE Revision 2 (Polska Klasyfikacja.., 2007).

The analysis of working capital management efficiency in the food industry referred to the indices of management efficiency of inventory, accounts receivables, current liabilities, and the period of cash conversion. In the analysis, simplified indices were applied, that were calculated by means of the following formulas (Sierpińska and Jachna, 2004)2:

Inventory turnover cycle $=\frac{\text { Average inventory x } 365}{\text { Net sales }}$

This cycle defines the frequency in days of refreshing the inventory by the enterprise or the period of cash freezing in the inventory. In the interpretation of this index, limit values are not stated as it is the most characteristic for this industry.

Receivables cycle $=\frac{\text { Average receivables x } 365}{\text { Net sales }}$

The receivables cycle informs of the number of days from the moment of sale (issuing of invoice) until receiving of payment. In other words, it shows to which extent the enterprise credits its receiver. The value of this index depends on numerous factors that do not allow the defining normative value ${ }^{3}$.

The inventory turnover cycle and receivables cycle determines the length of operating cycle that defines the time passed since purchasing of trade materials and goods to the moment of collection of accounts receivables from the sale of final products or goods. Efforts should be taken as much as possible to shorten it, mainly in order to reduce the cost of capital and advancing its rotation.

Short-term current liabilities

$\begin{aligned} & \text { Current liabilities } \\ & \text { payment cycle }\end{aligned}=\frac{\text { (excluding credits and loans) } \times 365}{\text { Net sales }}$

Granting a trade credit, the enterprises themselves use this instrument, that is they buy materials with deferred terms of payment. A measure of the current liabilities payment period is the cycle, the extension of which is beneficial for the enterprise in terms of liquidity risk, as it reduced the working capital demand. However, in a well-functioning enterprise, this cycle should not be unnecessarily prolonged, but synchronized with the operating cycle.

A part of operating cycle that is not financed by current liabilities determines a cash conversion cycle, which may be written as follows:

Cash conversion cycle $=$ Inventory turnover cycle + Receivables cycle - Current liabilities payment cycle

A positive direction change of this cycle is not so clear, as in the case of other cycles. It is beneficial when it oscillates around zero (Wędzki, 2009). A short conversion period may be a result of a short period of the operating cycle, and quite a long current liabilities cycle in the same time. It is beneficial for the enterprise, as it is then financed by the suppliers, although excessively long delays of payment may mean the absence of cash for current liabilities due. A long conversion cycle, in turn, resulting from a long operating cycle and a short current liabilities payment cycle may entail a non-moving inventory situation, and difficulties in debt collection and the suppliers' dissent on the enterprise crediting, which as a consequence, may lead to its bankruptcy (Wędzki, 2009).

In the assessment of working capital management efficiency, tools of regression analysis were also applied. Their aim was to establish a force and direction of influence of specific partial cycles and a synthetic cycle on the industry efficiency of enterprises measured by the return of non-financial (operating) assets (ROA).

\section{Working Capital Cycle and Rates of Return in the Food Industry of Selected Eurozone Countries and in Poland in 2005-2009}

Table 1 contains, comparatively for seven Eurozone countries and Poland, the length of cycles of inventory, accounts receivables, current liabilities and cash conversion (funds) along with the average return of assets $(\mathrm{ROA})^{4}$ in the food industry sector (production of foods and beverages) in these countries. Their analysis leads to a conclusion that small- and middle-sized enterprises in Belgium, Poland, Germany and Austria, where the cash freezing period in the inventory 

amounted to about 1 month, manage their inventory in the most efficient manner.

Small- and middle-sized companies from other countries, that is, Italy, Spain, Portugal and France, present significantly worse results. In small- and middle-sized enterprises of these countries, the inventory rotation was significantly slower, and it was translated in a much longer period of cash freezing in inventory equaling from 2 to 3 months.

In connection with the other countries, Polish small- and middle-sized food companies clearly stand out also in terms of accounts receivables management. Data listed in Table 1 indicate quite a rigorous crediting policy of receivers and, as a consequence, cash in small- and middle-sized food companies is frozen in accounts receivables for the relatively shortest time (about 1.5 month). Analyzing in turn the average length of these cycles in small- and middle-sized food companies of the other countries, it may be noted that they indicate on a significantly longer crediting period of receivers.

Data presented in Table 1 indicates that except for Austria, Germany and France, where the accounts receivables cycle was 54-77 days, in the sector of smalland middle-sized enterprises of the other countries, the accounts receivables were conversed in a cycle that usually exceeded 3 months.

The length of current liabilities cycle also quite clearly distinguishes small- and middle-sized food companies in Poland, Germany, Austria and France. In these countries, current liabilities were settled within no more than 2-2.5 months, whereas in Belgium, Spain, Italy, and Portugal, small- and middle-sized enterprises settled their current liabilities to suppliers in a cycle that exceeded 3-4 months.

The resultant of the partial working capital cycles analyzed above is the cash conversion cycle that synthetically presents the time elapsed from the cash disbursement for materials and raw materials through the production and sale until granting a trade credit and collection. The length cycle analysis shows that in the sector of small- and middle-sized food enterprises, the working capital in Poland, Belgium, Germany and Austria was managed in the most efficient manner. It was regenerated on average after 15-32 days (smallsized companies) and 30-49 days (middle-sized companies), whereas in the other countries, this period was 2-3 months. Yet, it is important to emphasize that the source of high efficiency measured with the cash conversion cycle in Poland, Belgium, Germany and Austria were quite clearly varied. For instance, in the national sector of small-sized food enterprises, it resulted mainly from a short operating cycle (inventory and accounts receivables cycle), whereas in Belgian enterprises, it resulted from a high inventory rotation strictly related with a longer settlement period.

Differences in specific partial working capital cycles were clearly smaller in the sector of large-sized food enterprises. The length of inventory cycle ranged about 30-50 days. This cycle was relatively shorter in largesized food companies in Germany, Poland, Belgium and Austria, where the inventory was regenerated within a cycle of about 1 month, whereas in the other countries, large-sized food enterprises reproduced their inventory every 40-50 days. Larger differences, in turn, are noticeable in the management of accounts receivables, where the average collection period ranged 53-111 days. On the basis of data presented in Table 1, it may be stated that the most rigorous policy of current liabilities settlement had large-sized food enterprises in Poland and Germany, and a more liberal one had Italian and Portuguese enterprises. In the abovementioned enterprises, accounts receivables were collected after less than 2 months, and 3-4 months, respectively.

The length of current liabilities cycle (50-100 days) differentiates the sector of large-sized enterprises to a similar extent. Financing of activity by means of current liabilities to suppliers played an important role above all, in the large-sized food enterprises in Belgium, Spain and Italy. In these countries, the cycle settlement of current liabilities was about 3 months, whereas in Poland, Germany and Austria, it did not exceed 2 months. The indicated differences in the policy of current liabilities and the differences in average collection period described above determine - to a large extent - the length of the cash conversion cycle, which is a measure of financial liquidity and efficiency of the working capital management. From these points of view, the most positive findings concerned large-sized food enterprises in Belgium, where the average cash conversion cycle amounted to 3 days $^{5}$ in the analyzed years. It means that it was close to a theoretical optimum. Large-sized food enterprises in Poland, Germa- 
ny and Spain have relatively efficient cash conversion. In these countries, the cash cycle was about 1 month, whereas in the other countries, it exceeded 50 days and reached almost 2 months.

In the light of the theory of finance as well as numerous empirical research described in the literature research, the policy of working capital management is strictly related with the obtained rates of return. This relationship is also apparent (Table 2) in terms of the sector mean from specific countries, although it does not apply to all the enterprise dimension classes.

Table 2. Linear correlation coefficients between the profitability and the length of working capital cycles estimated on the basis of the sector means from 2005-2009 in the structure of enterprise dimension (dimensions with ${ }^{* *}$ signify statistically significant correlations on the level of $\mathrm{p}<0.05$ )

\begin{tabular}{|l|l|l|l|}
\hline \multirow{2}{*}{ Cycles } & \multicolumn{3}{|c|}{ Enterprise dimension } \\
\cline { 2 - 4 } & small-sized & middle-sized & large-sized \\
\hline inventory cycle & 0.101 & $-0.902^{* *}$ & $-0.547^{* *}$ \\
\hline accounts receivables cycle & 0.245 & $-0.863^{* *}$ & $-0.617^{* *}$ \\
\hline current liabilities cycle & 0.132 & $-0.869^{* *}$ & $-0.354^{* *}$ \\
\hline cash conversion cycle & 0.224 & $-0.924^{* *}$ & $-0.378^{* *}$ \\
\hline
\end{tabular}

Source: own study on the basis of Bank for Accounts of Companies Harmonized.

In the case of small-sized food enterprises a weak correlation between the length of all the cycles and the assets return was noticeable. Nonetheless, this correlation was statistically significant. In the case of middle- and large-sized food enterprises in turn the analyzed correlation is very strong and in the same time, negative. It means that in respect to these classes of enterprise dimension, reducing the inventory, accounts receivables, current liabilities, and cash conversion cycles corresponded to a significant increase in the rate of return measured with the return on non-financial assets. Therefore, it may be stated that in terms of attainment of the most frequently indicated objective at present that is the value creation for stakeholders, the efficient management of working capital through reducing its element cycles is very significant.

\section{Trade Differentiation of Working Capital Cycles and Rates of Return in the National Food Industry in 2005-2009}

Table 3 shows the average period of cash conversion and partial indices constituting this period in small-, middle-, and large-sized food industry enterprises altogether and the production of groceries and beverages in Poland in 2005-2009. Moreover, basic descriptive statistics in the structure of enterprise dimension were presented. As the data contain therein indicate, the average inventory cycle of small-sized food enterprises was 31 days and it was very inconstant in the period under study. This cycle was similar in the department of groceries production, and it was much longer in the beverage production, which may result from their longer shelf life or be a sign of difficulties in the product sale.

In the light of the first quartile $\left(Q_{1}\right)$, in $25 \%$ of the food industry trades, the inventory cycle was not longer than 19 days and in $50 \%$ of trades, it was equal to or shorter than 30 days, and in $50 \%$ of trades, it was equal to or longer than 30 days $\left(\mathrm{Q}_{2}\right)$, whereas in $25 \%$ of trades, it amounted to 47 days and more $\left(Q_{3}\right)$. The distribution of food industry trades by the inventory cycle in 2005-2009 was characterized by a weak rightsided asymmetry $\left(\mathrm{A}_{\mathrm{sp}}=0.19\right)$, which implies that trades with a shorter-than-average inventory cycle prevailed. In specific food industry trades, the inventory cycle was very varied.

The shortest cycle (until 12 days) was in the enterprises representing trades related to meat processing and preservation, manufacturing of meat products, 
bread, fresh confectionery products and pastries, and ready-made dishes. The longest inventory cycle (over 2 months) was typical for the production of homogenized products and dietary food, beer, oils, vegetable and animal fats, sugar, and in the enterprises representing the trade of other processing and fruits and vegetables preservation.

Table 3. Working capital cycles and rate of return from non-financial assets in the food industry of selected Eurozone countries and in Poland by enterprise dimension ( $x$ - mean value, $v_{p}$-variation coefficient in \% from the period of 2005-2009)

\begin{tabular}{|c|c|c|c|c|c|c|}
\hline Specification & $\begin{array}{l}\text { Stock } \\
\text { cycle } \\
\text { (days) }\end{array}$ & $\begin{array}{l}\text { Receivables } \\
\text { cycle } \\
\text { (days) }\end{array}$ & $\begin{array}{l}\text { Operating } \\
\text { cycle } \\
\text { (days) }\end{array}$ & $\begin{array}{l}\text { Liabilities } \\
\text { cycle } \\
\text { (days) }\end{array}$ & $\begin{array}{l}\text { Cash conver- } \\
\text { sion cycle } \\
\text { (days) }\end{array}$ & $\begin{array}{l}\text { ROA } \\
\text { (\%) }\end{array}$ \\
\hline \multicolumn{7}{|c|}{ Small-sized enterprises } \\
\hline Food industry & 31.4 & 42.1 & 73.5 & 48.3 & 25.2 & 14.1 \\
\hline Groceries production & 29.1 & 41.2 & 70.3 & 43.5 & 26.8 & 14.4 \\
\hline Beverage production & 53.7 & 51.5 & 105.2 & 96.2 & 9.0 & 12.6 \\
\hline$x \min \pm x \max$ & $4,9-167,5$ & 21.3-155.4 & $32.0-220.7$ & $25.5-405.1$ & $-266.1-187.6$ & $-17.1-39.9$ \\
\hline Quartile 1 (Q1) & 17.3 & 37.1 & 61.0 & 39.4 & 6.1 & 7.8 \\
\hline Quartile 2 (Q2) & 30.4 & 50.7 & 84.0 & 50.1 & 28.2 & 14.0 \\
\hline Quartile 3 (Q3) & 46.8 & 67.3 & 119.8 & 73.4 & 53.3 & 19.0 \\
\hline Variation ratio vp (\%) & 45.1 & 29.8 & 35.0 & 33.9 & 83.7 & 39.9 \\
\hline Asymmetry ratio Asp & 0.19 & 0.10 & 0.22 & 0.37 & 0.06 & -0.12 \\
\hline \multicolumn{7}{|c|}{ Middle-sized enterprises } \\
\hline Food industry & 33.9 & 46.1 & 80.1 & 50.1 & 29.9 & 13.3 \\
\hline Groceries production & 35.0 & 43.5 & 78.5 & 46.0 & 32.5 & 13.8 \\
\hline Beverage production & 27.1 & 64.6 & 91.7 & 80.0 & 11.7 & 10.1 \\
\hline$x \min \pm x \max$ & $8.5-182.5$ & 20.4-91.7 & $37.8-259.7$ & $17.6-161.7$ & $-31.0-206.0$ & $-1.0-32.6$ \\
\hline Quartile 1 (Q1) & 20.0 & 36.1 & 73.6 & 40.1 & 13.9 & 10.5 \\
\hline Quartile 2 (Q2) & 35.7 & 54.2 & 90.3 & 53.5 & 34.0 & 12.8 \\
\hline Quartile 3 (Q3) & 54.5 & 64.9 & 121.0 & 64.4 & 67.2 & 17.4 \\
\hline Variation ratio vp (\%) & 48.3 & 26.5 & 26.2 & 22.8 & 78.4 & 26.9 \\
\hline Asymmetry ratio Asp & 0.09 & -0.26 & 0.29 & -0.11 & 0.25 & 0.33 \\
\hline \multicolumn{7}{|c|}{ Large-sized enterprises } \\
\hline Food industry & 29.2 & 46.6 & 75.7 & 53.3 & 22.5 & 18.1 \\
\hline Groceries production & 33.8 & 46.9 & 80.7 & 50.3 & 30.3 & 15.7 \\
\hline Beverage production & 13.0 & 45.4 & 58.5 & 63.6 & -5.1 & 26.5 \\
\hline$x \min \pm x \max$ & 9.3-131.2 & $25.0-82.7$ & $37.8-175.1 \mathrm{i}$ & $19.1-136.1$ & $-25.8-125.1$ & $5.6-39.2$ \\
\hline Quartile 1 (Q1) & 17.5 & 37.5 & 55.9 & 39.3 & 11.8 & 13.1 \\
\hline Quartile 2 (Q2) & 22.5 & 48.6 & 75.1 & 53.5 & 20.0 & 15.7 \\
\hline Quartile 3 (Q3) & 31.6 & 66.9 & 102.7 & 66.8 & 39.8 & 21.0 \\
\hline Variation ratio vp (\%) & 31.2 & 30.2 & 31.2 & 25.7 & 70.0 & 25.3 \\
\hline Asymmetry ratio Asp & 0.29 & 0.24 & 0.18 & -0.04 & 0.42 & 0.34 \\
\hline
\end{tabular}

Source: Own study based on the unpublished date of the Central Statistical Office 

The average length of the accounts receivables cycle in the sector of middle-sized food industry enterprises altogether, and enterprises producing groceries and beverages was similar, although it was slightly longer than in the small-sized enterprises. It means that they had a more liberal receiver-crediting policy. The average variability ( $\mathrm{vp}=26.5 \%)$ and a weak left-sided asymmetry was characteristic for the accounts receivables cycle in small-sized enterprises. It means that trades with a slightly longer-than-average accounts receivables cycle prevailed. In $25 \%$ of trades, the accounts receivables flowed in after over 2 months $\left(Q_{3}\right)$. The shortest accounts receivables cycle was typical for the same trades as in the case of small-sized enterprises. Also the longest cycles were characteristic for the same trades as in the small-sized enterprises, except for the ones producing soft drinks and mineral water that collected sales revenue in a period that was shorter by half.

The accounts receivables cycle of the middle-sized food industry enterprises, and the ones producing groceries was slightly longer than in the small-sized enterprises. However, it did not contribute to reaching a shorter cash conversion cycle than in the small-sized enterprises due to a relatively longer operating cycle. The accounts receivables cycle of the middle-sized enterprises producing beverages was shorter by 16 days in respect of the smallsized enterprises. This fact meant that the middle-sized enterprises had searched for additional financing sources only for about 12 days, whereas the other ones for about a month. Both small- and middle-sized food industry enterprises altogether and the ones producing groceries financed in $60 \%$ their operating cycle with current liabilities, whereas the enterprises producing beverages used this source of financing in $90 \%$.

Moderate variability and a weak left-sided asymmetry were characteristic for the current liabilities cycle of the middle-sized enterprises (trades with a longer than average current liabilities cycle slightly prevailed). The enterprises producing oils and liquid fats, cereal milling products, representing trades related to meat processing and preservation, and manufacture of meat products, and the ones producing milk, bread, and fresh confectionery products and pastries settled their current liabilities within no longer than 40 days.

The current liabilities cycle exceeded three months in the enterprises representing the trades of: distilleries, alcohol rectification and mixing, and production of sugar.
A strategy of financing the operating cycle with current liabilities adopted by the enterprises translates into the length of the cash conversion cycle. The distribution of food industry trades by the cash conversion cycle was characterized by significant variability and weak right-sided asymmetry (vp=78.4\%), which implies that trades with a shorter than average inventory cycle prevailed. In specific food industry trades, the inventory cycle was very varied. In the first quartile $\left(Q_{1}\right)$, in $25 \%$ of trades, the cash conversion cycle was shorter or at least equaled 14 days, in $50 \%$ of trades, it equaled or was shorter than 34 days, and in $50 \%$ of trades, it amounted to 34 days or more $\left(Q_{2}\right)$, whereas in $25 \%$ of trades, it was 67 days or more $\left(Q_{3}\right)$.

Enterprises representing the trades of: distilleries, alcohol rectification and mixing did not need external funds for financing their operating cycle (conversion period - minus 10 days). A short-term need (up to one month) was characteristic for the trades of: production of bread, fresh confectionery products and pastries (1 day), processing and preservation of poultry (2 days), production of soft drinks, mineral water and other bottled water (3 days), manufacture of meat products, and processing and preservation of meat (5 days), milk processing and cheese production (14 days), production of crackers and biscuits, production of preserved confectionery products and pastries (15 days), production of ice-cream (15 days), production of beer (22 days), and processing and preservation of fish, crustaceans, and mollusks (30 days). A long conversion cycle, which exceeded 2 months, was characteristic for enterprises processing and preserving potatoes, fruits and vegetables, producing spices, sugar, fruit and vegetable juices, processing tea and coffee, and the ones manufacturing cereal milling products, starch, and starchy products.

The return on assets (ROA) in the middle-sized food industry enterprises was on the same level as in the small-sized companies. Similarly as in the smallsized enterprises, the profitability was negatively correlated with the cycles of inventory, accounts receivables, and current liabilities in a moderate manner. It means that longer cycles were characterized by a lower profitability.

The inventory cycle in the large-sized food industry enterprises in Poland in the period of 2005-2009 was shorter than in the small- and middle-sized enterpris- 

cream, meat products, and processing and preserving meat products, processing milk, producing sugar, and producing ready-made animal feed paid their current liabilities within 50 days. In turn, the current liabilities cycle in the enterprises producing ready-made dishes, and the ones producing oils and fats was longer than 3 months.

Prolonging of the current liabilities cycle in the largesized food industry enterprises reduced the number, on average to 22 days, when they needed additional external financing. The distribution of food industry trades by the cash conversion cycle was characterized by very significant variability $\left(\mathrm{v}_{\mathrm{p}}=70 \%\right)$, and a weak right-sided asymmetry, which implies that trades with a shorter than average inventory cycle prevailed.

Enterprises representing the trades of: production of beer, production of crackers and biscuits, production of ready-made dishes did not need external funds for financing their operating cycle. A short-term need (up to one month) was characteristic for the trades of: manufacture of meat products, and processing and preservation of meat, production of bread, production of soft drinks and mineral water, milk processing and cheese production, processing of tea and coffee, production and preservation of potatoes. A long cash conversion cycle of over 2 months was present only in the enterprises producing sugar, and the ones processing and preserving fruits and vegetables.

In 2005-2009, large-sized food industry enterprises obtained a higher return on non-financial assets (ROA) by about 5 percentage points than the small- and middle-sized food industry enterprises. Nonetheless, similarly as in the small- and middle-sized companies, the profitability was negatively correlated with the cycles of inventory, accounts receivables and current liabilities, which means that a decrease in the profitability was typical for longer cycles.

\section{Quantitative Analysis of the Influ- ence of Working Capital Cycles on Rates of Return in the Food Industry in Poland in Years 2005-2009}

Table 4 presents coefficients of linear regression equations between the value of the coefficient of return on non-financial assets $\left(\mathrm{F}_{\mathrm{ROA}}\right)$ and statistically significant explanatory variable (on the significance level of $\mathrm{p}=0.05$ ), and determination coefficient $\left(\mathrm{R}^{2}\right)$ in the sector of small-, middle-, and large-sized food industry enterprises estimate on the basis of the trade sectional and dynamic data ${ }^{6}$. In order to identify the force and direction of the influence of specific partial cycles (of inventory, accounts receivables, and current liabilities) and the synthetic cycle (of cash conversion) on this category of return, Table 4 presents four separate regression functions $\left(\mathrm{Y}_{\mathrm{ROA}(\mathrm{I}-4)}\right)$. Such a procedure results, on the one hand, from a strong correlation between specific cycles and, on the other hand, it allows verification of hypotheses on the influence of each of the cycle on the return.

The analysis of regression models estimated for specific dimensions of the food industry enterprises allows the following conclusions to be drawn:

1. The independent variables adopted in the model explained, to a different but satisfying extent, the variability of return on non-financial assets (ROA), in the largest sector of the small-sized food companies $\left(\mathrm{R}^{2}=50-61 \%\right)$, to a lower extent in the middle- $\left(\mathrm{R}^{2}=26\right.$ $40 \%)$ and large-sized enterprises $\left(\mathrm{R}^{2}=29-34 \%\right)$.

2. Negative values of regression coefficients with the variables of: inventory cycle (X;), accounts receivables cycle $\left(\mathrm{X}_{2}\right)$, current liabilities cycle $\left(\mathrm{X}_{3}\right)$ and cash conversion cycle $\left(\mathrm{X}_{4}\right)$ indicate unequivocally that prolonging of these cycles has a negative influence on the return of assets in the small-, middle-, and large-sized food industry enterprises.

3. The analysis of regression coefficients with the variables describing the length of cycles indicates that in the sector of small-sized food industry enterprises, prolonging the inventory and current liabilities cycles negatively influenced the profitability in the strongest manner. In the period under study, prolonging these cycles on average by 10 days translated into a decrease in the profitability by about 1.4 percentage point, whereas the similar prolonging of other cycles (of current liabilities and cash conversion) reduced this return by $0.5-0.7$ percentage point.

4. The analysis of regression function parameters with the variables describing the length of cycles indicates that in the sector of small-sized food industry enterprises, prolonging the current liabilities cycle negatively influenced the profitability in the strongest manner. In the period under study, prolonging these cycles on average by 10 days translated into a decrease in the profitability by about 1.1 percentage 
Table 4. Linear regression and beta $(p)$ coefficients between the ratio of the return on non-financial assets $Y_{\text {ROA }}$ and statistically significant independent variables $X$, by the food industry enterprise dimension

\begin{tabular}{|c|c|c|c|c|}
\hline \multirow{2}{*}{ Independent variable $X_{1}$} & \multicolumn{4}{|c|}{ Dependant variable $Y_{\mathrm{BOA}}$} \\
\hline & $Y_{R O A(1)}$ & $\mathrm{Y}_{\mathrm{ROA}(2)}$ & $Y_{R O A(3)}$ & $Y_{R O A(4)}$ \\
\hline \multicolumn{5}{|c|}{ Regression coefficients $^{2}$} \\
\hline \multicolumn{5}{|c|}{ Small-sized enterprises sector $(\mathrm{N}=112)$} \\
\hline$X_{1}$ & $-0.1415(0.0000)$ & & & \\
\hline $\mathrm{X}_{2}$ & & $-0.1468(0.0000)$ & & \\
\hline$x_{3}$ & & & $-0.0532(0.0013)$ & \\
\hline$X_{4}$ & & & & $-0.0771(0.0001)$ \\
\hline $\mathrm{X}_{7}$ & $-2.7902(0.0405)$ & $-3.7521(0.0003)$ & $-6.9604(0.0000)$ & $-4.1608(0.0004)$ \\
\hline $\mathrm{X}_{8}$ & $8.2169(0.0000)$ & & $7.8347(0.0000)$ & $9.4927(0.0000)$ \\
\hline$X_{9}$ & & $11.2103(0.0000)$ & & \\
\hline$X_{12}$ & $-0.1494(0.0055)$ & $-0.1695(0.0003)$ & & $-0.2923(0.0000)$ \\
\hline$X_{14}$ & $-0.1878(0.0374)$ & & $-0.2997(0.0006)$ & \\
\hline Equation constant & $42.39(0.0004)$ & $53.39(0.0000)$ & $68.64(0.0000)$ & $55.77(0.0000)$ \\
\hline $\mathrm{R}^{2}(\%)$ & 58.69 & 61.05 & 50.85 & 57.78 \\
\hline \multicolumn{5}{|c|}{ Middle-sized enterprises sector $(\mathrm{N}=116)$} \\
\hline$X_{1}$ & $-0.0523(0000)$ & & & \\
\hline $\mathrm{X}_{2}$ & & $-0.1108(0.0007)$ & & \\
\hline$X_{3}$ & & & $-0.0512(0.0400)$ & \\
\hline$X_{4}$ & & & & $-0.0549(0.0000)$ \\
\hline$X_{12}$ & $-0.2383(0.0000)$ & $-0.2735(0.0000)$ & $-0.1618(0.0009)$ & $-0.2907(0.0000)$ \\
\hline$X_{14}$ & $0.3496(0.0011)$ & $0.3109(0.0072)$ & & $0.3684(0.0003)$ \\
\hline$x_{16}$ & $-0.3159(0.0234)$ & $-0.3573(0.0114)$ & $-0.4366(0.0057)$ & $-0.2989(0.0264)$ \\
\hline Equation constant & $27.54(0.0000)$ & $33.30(0.0000)$ & $26.68(0.0000)$ & $30.20(0.0000)$ \\
\hline $\mathrm{R}^{2}(\%)$ & 36.44 & 33.92 & 26.53 & 40.54 \\
\hline \multicolumn{5}{|c|}{ Large-sized enterprises sector $(\mathrm{N}=94)$} \\
\hline$X_{1}$ & $-0.1017(0.0003)$ & & & \\
\hline$x_{2}$ & & $-0.1304(0.0092)$ & & \\
\hline$x_{3}$ & & & $-0.0933(0.0305)$ & \\
\hline$X_{4}$ & & & & $-0.1218(0.0000)$ \\
\hline$X_{10}$ & & $-0,1272(0,0455)$ & $-0,1597(0,0111)$ & \\
\hline$X_{12}$ & $-0,2536(0,0028)$ & $-0,2873(0,0002)$ & $-0,1849(0,0395)$ & $-0,4262(0,0000)$ \\
\hline$X_{13}$ & & $-0,2003(0,0260)$ & $-0,2812(0,0144)$ & \\
\hline$X_{14}$ & $-0,2996(0,0436)$ & & & \\
\hline Equation constant & $36,04(0,0000)$ & $48,49(0,0000)$ & $44,35(0,0000)$ & $43,51(0,0000)$ \\
\hline $\mathrm{R}^{2}(\%)$ & 30,58 & 30,81 & 29,15 & 33,99 \\
\hline
\end{tabular}

Source: Own study

$X_{1}$ - inventory cycle (days), $X_{2}$ - accounts receivables cycle (days), $X_{3}$ - current liabilities cycle (days), $X_{4}$ - cash conversion cycle (days), $X_{7}$ - enterprise dimension (natural logarithm of assets value), $X_{8}$ - current ratio (current assets/current current liabilities), $X_{9}-$ quick ratio (current assets - inventory)/current current liabilities, $X_{10}$ - share of current assets in total assets (current assets $\times 100 /$ total assets), $X_{12}$ - total debit (current liabilities and reserves $\times 100$ )/total assets, $X_{13}$ - financial debit (long- and short-term credits and loans $\times 100 /$ total assets), $X_{14}$ - short-term financial debit (total assets $\times 100$ )/total assets, $X_{16}$ - share of financial fixed assets in total assets in \%. 2 Parameters describing the influence of the cycles of inventory, accounts receivables, current liabilities, and cash conversion on the return were written in bold; values in brackets at regression coefficients inform about the significance level of independent variables $X_{i}$. 
point, whereas the similar prolonging of other cycles (of inventory, current liabilities and cash conversion) reduced this return by 0.5 percentage point.

5. In the sector of large-sized enterprises, a negative influence of all the cycles under study on the profitability was very similar. In the period under study, prolonging these cycles on average by 10 days translated into a decrease in the profitability by about 0.9-1.3 percentage point.

6. An increase in the assets value $\left(\mathrm{X}_{7}\right)$ and debt $\left(\mathrm{X}_{12} \mathrm{X}_{14}\right)$ also negatively influenced the return on non-financial assets in the sector of small-sized enterprises. These variables influence the return in a manner indicating that in a part of small-sized enterprises, the assets are used inefficiently, and a high level of debt may cause difficulties maintaining financial liquidity. It appears that in this case, the problem of liquidity is particularly important and it is reflected in the impact of $\mathrm{X}_{8}$ and $\mathrm{X}_{9}$ variables. The data presented in Table 4 shows that the increase in liquidity measured by the current $\left(\mathrm{X}_{8}\right)$ and quick $\left(\mathrm{X}_{9}\right)$ ratio corresponded to the positive growth of the profitability.

7. In the sector of middle- and large-sized enterprises, no statistically significant relationship between the profitability and the level of current and quick ratios was observed. Nonetheless, in these dimension classes, variables reflected different debt categories were usually negatively correlated with the rate of the profitability. It appears that this condition may result from constantly decreasing efficiency of investment in operating assets.

\section{Conclusion}

The efficiency of working capital management may be assessed by means of the cycles of inventory, accounts receivables, current liabilities, and cash as well as through their reference to the obtained rate of the profitability. This efficiency varied both in specific Eurozone countries and in the enterprises of different dimension. In the national food industry, the large-sized enterprises presented the highest efficiency measured by the cash conversion cycle and the profitability. It should be underlined, however, that both large-sized enterprises and the small- and middle-sized ones, the profitability was negatively correlated with the cycles of inventory, accounts receivables and current liabilities, which means that prolonging these cycles translated into a decrease in the profitability. These types of relationships were confirmed by the created regression models.

\section{Bibliogrphy}

1. Afza T., Nazir M. (2009). Impact of aggressive working capital management policy on profitability of firms. The IUP Journal of Applied Finance, vol. $15(8):$ 20-30.

2. Deloof M. (2003). Does working capital management affect profitability of Belgian firms? Journal of Business Finance \& Accounting vol. 30(3-4): 573-588.

3. Dong H.P., Su J. (2010). The relationship between working capital management and profitability: a Vietnam case. International Research Journal of Finance and Economics vol. 49: 59-67.

4. Gentry J. A., Vaidyanathan R., Lee H. W. (1990). A weighted cash conversion cycle. Financial Management vol. 19: 90-99.

5. Gill A., Biger N., Mathur N. (2010). The relationship between working capital management and profitability: evidence from The United States. Business and Economics Journal vol. 10: 1-9.

6. Howorth C., Westhead P.( 2003). The focus of working capital management in UK small firms. Management Accounting Research vol. 14: 94-111.

7. Lazaridis J., Tryfonidis D. (2006). Relationship between working capital management and profitability of listed companies in the Athens inventory exchange. Journal of Financial Management and Analysis vol. 8. 19(1): 26-35.

8. Lyroudi K., Lazaridis J. (2000). The cash conversion cycle and liquidity analysis of the food industry in Greece. Social Science Research Network. Dostępne na: http://papers.ssrn.com

10. Mohamad N.E.A, Saad N.B.M. (2010). Working capital management: The effect of market valuation and profitability in Malaysia. International Journal of Business and Management vol. 5(11): 140-147.

9. Nabone H., Abdullatif M., Al Hajjar M. (2010). Cash conversion cycle and firm's performance of Japanese firms. Social Science Research Network. Dostępne na: http://papers.ssrn.com .

10. Niepublikowane dane Głównego Urzędu Statystycznego: F0-2, statystyczne sprawozdanie fi- 
nansowe, produkcja artykułów spożywczych, produkcja napojów, GUS, Warszawa, 2011.

11. [Unpublished Data of the Central Statisitical Office: F0-2, statistical financial statement, groceries production, bevereages production, GUS, Warsaw, 20011.]

12. Ózbayrak M., Akgiin M. (2006). The effects of manufacturing control strategies on the cash conversion cycle in manufacturing systems. International Journal of Production Economics, vol. 103: 535-550.

13. Padachi K. (2006). Trends in working capital management and its impact on firm performance: An analysis of Mauritian small manufacturing firms. International Review of Business Research Papers vol. 2: 45-58

14. Polska Klasyfikacja Działalności - PKD: Załącznik do rozporządzenia Rady Ministrów z 24.12.2007, Dz. U. 251, poz. 1885, GUS, Warszawa, 2007. Dostępne na: http://www.stat.gov.pl/

15. [Polish Classification of Activity - PKD: Annex to Ordinance of the Council of Ministers of December 24, 2007, Official Journal 251, item 1885, Central Statisitical Office, Warsaw, 2007. Available on: http://www.stat.gov.pl/]

16. Raheman A., Nasr M. (2007). Working capital management and profitability - Case of Pakistani firms. International Review of Business Research Papers vol. 3(1): 279 - 300.

17. Ramachandran A., Janakiraman M. (2009). The Relationship between working capital management efficiency and EBIT. Managing Global Transitions v. 7(1): 61-74.

18. Richards, V.D., E.J. Laughlin (1980). A cash conversion cycle approach to liquidity analysis. Financial Management vol. 9: 32-38.

19. Shin H. H., Soenen L. (1998). Efficiency of working capital management and corporate profitability. Financial Practice and Education vol.8(2): 37-45.

20. Sierpińska M., Jachna T. (2004). Ocena przedsiębiorstwa według standardów światowych. Warsaw:

21. PWN. [Enterprise Assessment by Means of World Standards, Warsaw: PWN]

22. Van Horne J. C., Wachowicz J. M. (2004). Fundamentals of Financial Management (12 ed.). New York: Prentice Hall.
23. Wędzki D. (2009). Analiza wskaźnikowa sprawozdania finansowego, Tom 2. Wskaźniki finansowe. Kraków: Oficyna Ekonomiczna.

24. [Ratio Analysis of the Financial Statement. Vol. 2. Financial Ratios. Cracow: Oficyna Ekonomiczna]

\section{Notes}

1. Data is presented by economy sectors, according to the Classification of Economic Activities in the European Community (NACE Revision 1.1 i 2). Yet, they do not concern all the Eurozone countries, and they are often incomplete and incomparable in time, and a division of companies by dimension does not conform to the Classification adopted by the EU. Poland has participated in the Bank for Accounts of Companies Harmonised program for two years.

2. Simplified formulas of calculation of the length of specific cycles were applied in the analysis. However, it is important to emphasize that the reference books contain various calculation formulas of these cycles, which significantly diverge from the primary idea of Richards and Laughlin (1980).

3. Yet, some authors undertake to determine them. In Poland, it is estimated that the length of average collection period in the industry enterprises should amount to about 60 days (Sierpińska and Jachna, 2004). Wędzki (2009), in turn, states that receivables are collected after 45 days, although the suppliers indicate the payment period of 7 to 21 days.

4. $\mathrm{ROA}=$ (operating profit + amortization) $\times 100 \%$ / (assets total - long-term investments, long-term receivables, short-term investments + cash).

5. Significant differences in specific years.

6. In the analysis of quantitative relationships of working capital cycles with the return of non-financial assets, there was applied a set of variables that was verified in the studies and previously quoted in the literature research. In these studies, variability of the profitability in reference to the length of working capital partial cycles was also analyzed in connection with the structure of current assets, the level and structure of current liabilities, financial liquidity ratios, the enterprise dimension measured by the value of revenues and assets, and the level of long-term financial assets. 